\title{
Characteristics of the Tapanuli Orangutan Habitat in the Conflict Area of Batang Toru Landscape, North Sumatra, Indonesia
}

\author{
Wanda Kuswanda ${ }^{1,5^{*}}$, R. Hamdani Harahap ${ }^{2^{*}}$, Hadi S. Alikodra ${ }^{{ }^{*}}$ and Robert Sibarani ${ }^{4^{*}}$ \\ ${ }^{1}$ Post-graduate Program in Environmental and Natural Resources Management, University of Sumatera \\ Utara, Medan, Indonesia \\ 2 Faculty of Social and Political Science, University of Sumatera Utara, Medan, Indonesia \\ ${ }^{3}$ Faculty of Forestry, Bogor Agricultural University, Bogor, Indonesia \\ ${ }^{4}$ Faculty of Cultural Science, University of Sumatera Utara, Medan, Indonesia \\ ${ }^{5}$ Environmental and Forestry Research and Development Institute of Aek Nauli, Indonesia \\ * Correspondence author: wkuswan@yahoo.com; r.hamdani@usu.ac.id; halikodra.ha@gmail.com; \\ rs.sibarani@usu.ac.id
}

\begin{abstract}
Forest fragmentation has resulted in decreased wildlife habitat, which has triggered conflicts with humans due to the use of the same plants. This has been particularly contentious with the tapanuli orangutan. Research of the tapanuli orangutan (Pongo tapanuliensis) habitat is very limited. The aims of this research is to examine the latest habitat conditions, such as land cover, composition of vegetation, feed plant, and habitat carrying capacity to provide recommendations for habitat management in developing a mitigation policy of the human-tapanuli orangutan conflict. The research location is focused on the area of human-orangutan conflict in the Batang Toru Landscape in South Tapanuli Regency, which took place from August to December 2019. Vegetation analysis was conducted using the strip transect method with a total of 294 plots (11.76 ha). The number of species at the pole and tree levels were high with 149 species (46 families) and diversity index $\left(\mathrm{H}^{\prime}\right)>3$. Eighty feed plant species were found and expected to support the growth of the orangutan population of 247 individuals. The density and diversity of cultivated plant species in the buffer zone were high and consumption by orangutans resulted in human-tapanuli orangutan conflict, especially on durian (Durio zibethinus Murray). Conflict with humans will cause stress and disruption to the growth of the tapanuli orangutan. We recommend habitat management to mitigate conflict through patrols for monitoring habitat destruction in conservation forests, enrichment of feed plants in Forest Management Units, cultivation of orangutan non-food crops on community lands, and building a corridor with orangutan food crops with fruits that are not utilized by humans.
\end{abstract}

Keywords: vegetation; food plant; orangutan; Batang Toru; Tapanuli

\section{Introduction}

Tropical forests have become a habitat for wildlife species that can provide resources, of both biotic and abiotic components, for survival and reproduction (Morrison et al., 2012). Habitat is used as a place to forage, look for partners, sleep, nest, and conduct social and all other activities by living organisms in their home range (Pinnoti et al., 2012; Alikodra, 2019). Exploitations of tropical forests by humans in various countries have resulted in more than $50 \%$ of primary forests being degraded and fragmented and have pushed wildlife to a threatened state (Garcia et al., 2020).

The forest conversion in Sumatra, Indonesia, into agricultural lands, plantations, and settlements has decreased the carrying capacity of the wildlife habitat (Tsujino et al., 2016; Scanes, 2018). Habitat fragmentation leads to loss of home range (Córdova-Lepe et al., 2018; Daniel et al., 2020) and isolation of wildlife in limited areas by human activities, including in protected areas and conservation forests (Maldonado et al., 2013; Neelakantan et al., 2019). The orangutan is one of the species threatened by habitat destruction of more than $50 \%$, especially in unprotected forests (Hardus et al., 2012; Wich et al., 2016; Meijaard et al., 2018). 
Habitat of the Tapanuli orangutan (Pongo tapanuliensis) is limited in the Batang Toru Landscape, North Sumatra, Indonesia. The orangutan can be found from lowland forests ( $300 \mathrm{~m}$ above sea level) to mountain forests $(1,500 \mathrm{~m}$ above sea level), including habitats in state forests (nature reserves and production forests) and other use areas/cultivated lands (Djojoasmoro et al., 2004; Kuswanda, 2014; Wich et al., 2014; Ministry of Environment and Forestry, 2019). The Tapanuli orangutan habitat is estimated at $58.52 \%$ of the entire Batang Toru Landscape (Rahman et al., 2019). The remaining population is at a size of $577-760$ and is fragmented by a road that divides into two habitat blocks, the West Block and the Eastern Block as shown in Figure 1 (Ministry of Environment and Forestry, 2019).

Research related to the habitat conditions of the Tapanuli orangutan is very small and is inclusive of limited sites, e.g., Kuswanda and Sugiarti (2005), Simorangkir (2009), and Nasution et al. (2018). Information describing the vegetation composition and feed plants on a landscape scale is not yet available. It is important to update information on the habitat characteristics amid the massive forest conversions taking place in the Batang Toru Landscape. One of the priority locations is an area of conflict with humans because of the high rates of forest degradation and conversion into cultivated lands, which greatly threaten the orangutans (Wich et al., 2016; Scanes, 2018; Haryanto et al., 2019).

Human and orangutan conflicts consist of interactions that have had negative effects on human life and orangutan conservation. Orangutan conflicts increase with the extent of forest conversion and disturbance of animals on community crops (Ministry of Forestry, 2014; Atmoko et al., 2014; Abram et al., 2015; Buckley et al., 2016). Human-orangutan conflicts on the island of Sumatra have occurred in each of their habitats, such as in Gunung Leuser National Park (Aceh Province), Bukit Tigapuluh National Park (Riau) and Siranggas Wildlife Reserve and Batang Toru Landscape (North Sumatra). Human-tapanuli orangutan conflicts in the last three years have increased in villages around the conservation forest, South Tapanuli Regency. The conflicts were triggered by the increasing human growth rate, expanding cultivation lands and community activities in the conservation forest, and damage to community plants, especially in buffer villages. The conflict can also be caused by orangutans entering gardens to be evicted because they are considered to be plant pests by farmers, such as in the villages of Sipirok and Arse Sub-districts (Kuswanda, 2014; Wich et al., 2016; Nater et al., 2017; Uddin et al., 2020).

Tapanuli orangutan information is still very limited, especially on the landscape scale, because research is still focused on Sumatran orangutans/Pongo abelii (Kuswanda, 2014; Nater et al., 2017). One of the important areas of further inquiry are to develop mitigation measures of humanorangutan conflict by better understanding of the characteristics of the remaining habitat (Atmoko et al., 2014). We therefore researched information on habitat characteristics, including land cover type, vegetation composition, feed plants, and habitat carrying capacity in the conflict areas. The results of the research can be a consideration for developing policies in mitigating human-tapanuli orangutan conflict by a wide range of stakeholders, in South Tapanuli Regency, Batang Toru Landscape, Indonesia.

\section{Materials and Methods}

\subsection{Study Site}

The Batang Toru area is a landscape that has types of ecosystems with a high diversity of flora and fauna (Haryanto et al., 2019). Ecosystem types in Batang Toru range from lowland (300 meters above sea level) to sub-Montane to high mountain forests (1,800 meters above sea level). The wildlife identified consisted of 67 species of mammals, 287 species of birds, 19 species of amphibians, and 49 species of reptiles. The vegetation was found to consist of around 688 species (137 families), including trees, herbs, shrubs, and lianas (Perbatakusuma et al., 2006). This area is $2,750 \mathrm{~km}^{2}, 1,383.4 \mathrm{~km}^{2}$ of which is potential for orangutan habitat. Administratively, the Landscape 
is included in three districts: North Tapanuli, Central Tapanuli, and South Tapanuli, North Sumatera (Figure 1).

The research was focused on South Tapanuli because the conversion rate of forest cover into cultivated land is fast, leading to frequent human-orangutan conflicts in Tapanuli (Kuswanda, 2014; Haryanto et al., 2019). Kuswanda et al. (2020) stated that the conflict area in South Tapanuli District was estimated at 29,192 ha with an orangutan population of 155 individuals. This area includes 20 villages in four sub-districts with a population of around 17,347 people. The livelihoods are $88 \%$ as farmers with an income of $75 \%$ below IDR 4,000,000, such as in Sipirok and Marancar Sub-district. The land types managed by communities in conflict areas include mixed gardens and monoculture crops, agroforestry, rice fields, and vegetables. The area of land managed by the community in each village and sub-district is different. For example in Kecamatan Sipirok the cultivated lands reached 11,000 ha (BPS-Statistics of South Tapanuli Regency, 2019). Stakeholders that have an interest in orangutan habitats in the Batang Toru Landscape include the Center for Conservation of Forest Resources in North Sumatera working on the conservation forest, the buffer zone areas where the local government and the communities of the South Tapanuli are located (namely the "other use areas" or non-forest areas/area penggunaan lain), Forest Management Units (Kesatuan Pengelolaan Hutan/KPH), and the private sector.

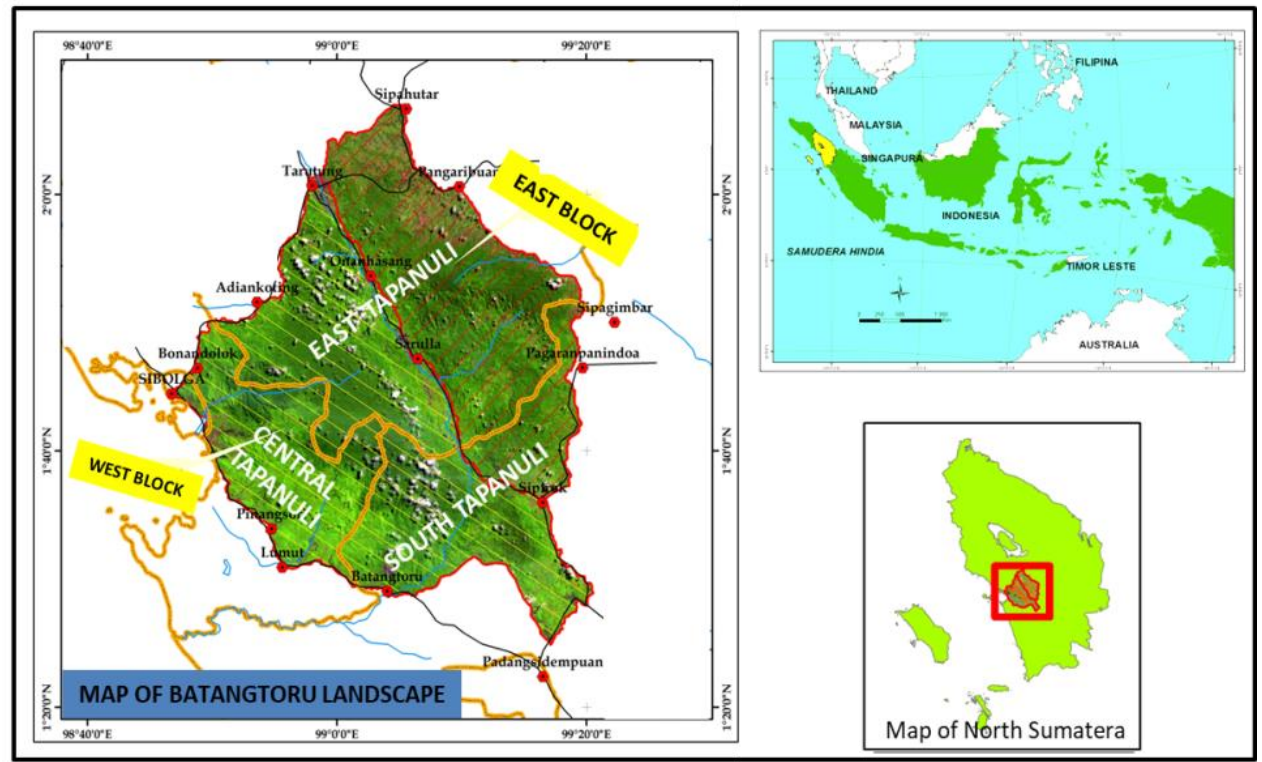

Figure 1. Map of Batang Toru Landscape, North Sumatra, Indonesia

\subsection{Data collection}

We selected the research sites using the stratified random sampling method based on habitat blocks and forest status. The remaining orangutan habitat in South Tapanuli Regency covered $521.24 \mathrm{~km}^{2}$, including the East Block $\left(89.25 \mathrm{~km}^{2}\right)$, the West Block $\left(213.31 \mathrm{~km}^{2}\right)$, and the West Block (South) $\left(202.67 \mathrm{~km}^{2}\right)$. Status-wise, the forest consisted of conservation areas and buffer zones (production forests and other use areas). Vegetation plots were assigned by making 49 line transects $500 \mathrm{~m}$ each (Tabares et al., 2018). Each habitat block was assigned with transects in proportional numbers, as in Figure 2. In each transect, 6 plots of vegetation were systematically sampled every $100 \mathrm{~m}$. In total 294 plots (11.76 ha) were created, including 108 plots in the conservation forests and 186 in the buffer zones. Vegetation analysis was done using the strip transect method according to Alatar et al. (2012) and Lillo et al. (2019). The vegetations are defined as flora that grow naturally 
and are planted. These were restricted to pole and tree level observations because orangutans are arboreal, or living in tree canopies (van Casteren et al., 2012; Wich et al., 2012).

The plot size of the pole (diameter at breast height, $d b h: 10-20 \mathrm{~cm}$ ) is $10 \mathrm{~m} \times 10 \mathrm{~m}$, and the plot size of the tree $(\mathrm{dbh}>20 \mathrm{~cm})$ is $20 \mathrm{~m} \times 20 \mathrm{~m}$ (Bookhout, 1994; Fahrul, 2007). The data observed included land cover types (Indonesian National Standard/SNI 7645-1, 2014), tree species, plants consumed by orangutans, and diameters. Identification of orangutan food plants was conducted by direct observations, interviews, and literature studies. The botanical names refer to the book series of Flora Malesiana (Indonesian Institute of Sciences, 1982) and the collection of Botanical Laboratory, Research and Innovation Agency, Ministry of Environment and Forestry, Indonesia. We also conducted descriptive observations to obtain information on potential human-orangutan conflict, especially on community cultivated lands (Rakshya, 2016)

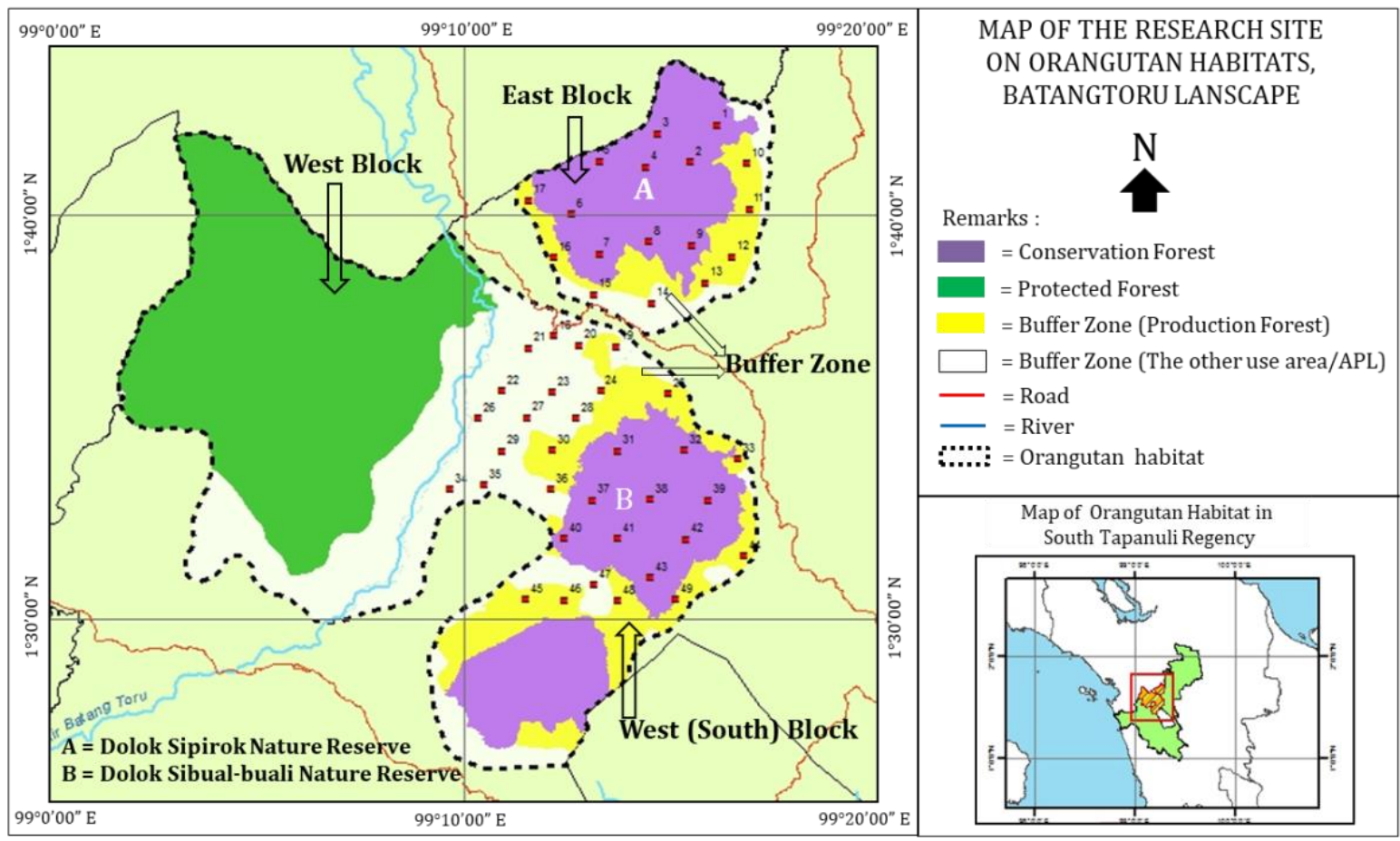

Figure 2. Location of vegetation plots in the area of human-Tapanuli orangutan conflict

\subsection{Data Analysis}

The vegetation composition was analyzed using the Importance Value Index (IVI) at the pole and tree levels. Equations for calculating density, dominance, frequency, and INP values refer to Fachrul (2007), Morrison et al., (2012), and Kuswanda and Sunandar (2019). The species diversity was calculated using the Shannon-Wiener index (Shannon, 1948), and the species abundance with the Hill index (Alatar et al., 2012; Tabares et al., 2018; Geng et al., 2019), its criteria referring to Barbour et al. (1987). Estimation of the carrying capacity in each habitat block followed Kuswanda and Bismark (2007), Ismail and Jiwan (2015), and Chapman and Byron (2018). Information on potential and mitigation strategies of the human-Tapanuli orangutan conflict was analyzed qualitatively through ongoing engagement on the issues throughout the analysis period (Harahap and Humaizi, 2018).

\section{Results and Discussion}

\subsection{Composition of Vegetation}

\subsubsection{Type of Land Cover}


Information on land cover in a wildlife habitat can describe habitat changes for species conservation management (Kosmidou et al., 2014), criticality of habitat, and reference to a species protection technique (Nelson et al., 2017). Referring to the Indonesian National Standard/SNI 76451 (2014), six types of land cover were identified in the orangutan habitat in the conflict areas of South Tapanuli Regency. The primary forests (no disturbance by human activities) covered $30.61 \%$, and $90 \%$ were covered only by conservation forests (nature reserves). The other types were secondary forests at $28.57 \%$, agroforestry at $17.69 \%$, monoculture land at $13.27 \%$, mixed forest at $9.18 \%$ and rice fields at $0.68 \%$.

Primary forests are a habitat favored by orangutans because they provide nesting trees and food sources, especially fruits (Bastian et al., 2012). The buffer zones were decreasing because most the forests had been disturbed by human activities, such as through logging, land clearing, and infrastructure development (Ango et al., 2017), except for the production forests that have steep topography or community water sources. The conversion of primary forests into cultivated lands by the community provided economic resources but resulted in a reduction in wildlife habitat and triggered human conflicts with wildlife (Wich et al., 2016; Vesco et al., 2020). The species of plants cultivated include rubber, durian, sugar palm (Arenga pinnata Merr), coffee, cacao, and cinnamon. In secondary forests and agroforestry lands, habitat components required by wildlife (feed, nesting sites, or shade trees) were reduced and limited, such as red meranti (Shorea lefrosula Miq), hoteng/pasang (Quercus gemelliflora Blume), mayang (Palaquium gutta Burch), and teurop (Artocarpus elasticus Reinw. Ex BI.). Wildlife population would be trapped in areas with low carrying capacity such as nature reserves (Dickman, 2010; Nelson et al., 2017), and to get food they would move to agroforestry land and mixed forests (Megaze et al., 2017). Agroforestry land with a mixture of coffee (Coffea sp.), cacao (Theobroma cacao L.), durian (Durio zibethinus Murray), petai (Parkia speciosa Hassk), and sugar palm also causes orangutans to live and settle on community land because it provides a source of food for them and has provided the grounds for conflicts to spread (Kuswanda, 2014).

Monocultural farming systems (single species cultivation) in the Batang Toru Landscape began to develop in the early 1970s, especially in the West (South) Block, with cultivation of plants like rubber (Hevea brasiliensis Muell Arg), oil palm (Elaeis guineensis Jacq), salak (Salacca zalacca Gaertner Voss), coffee, cinnamon (Cinnamomum burmannii Nees \& Th. Nees), and some cocoa. These farming systems increased after the high rate of land purchased by urban people from the local community, such as from Medan, Padang, and Java. Their presence has replaced the model of land use by plants whose products are meant for sale, such as latex and fruit (Templeton et al., 2019). Agricultural lands such as rice fields were found on flat lands adjacent to residential areas or rivers. The development of monoculture land caused the isolation of orangutans, natural food trees to decline, and the more frequent visits to community lands that cultivate plants preferred by orangutans, such as agroforestry land dominated by durian.

\subsubsection{Importance value index}

In this study, the importance value index analysis was limited to plants at the tree level (dbh> $20 \mathrm{~cm}$ ) and poles $(\mathrm{dbh}>10-20 \mathrm{~cm}$ ) which are used by Tapanuli orangutans for foraging, nesting, moving, and other activities (Meijaard et al., 2001; van Casteren et al., 2012). Based on the observations in the 294 plots ( 11.76 ha), we identified 149 species of plants from 46 families at the tree and pole levels. In the Eastern Block, 101 species (36 families) were found, including 84 species in Dolok Sipirok Nature Reserve (67 at the tree and 53 at the pole) and 95 species in the buffer zones (77 at the tree and 69 at the pole). In the West Block (South), 136 species (44 families) were found, consisting of 85 species in the Dolok Sibual-buali Nature Reserve ( 76 at the tree and 62 at the pole) and 121 species in the buffer zones (102 at the tree and 91 at the pole).

We have analyzed the density, frequency, and dominance values at each study location as shown in Table 1. 
Table 1. Density, frequency, and dominance in the area of human-orangutan conflict

\begin{tabular}{|c|c|c|c|c|c|c|}
\hline Block & Site & $\begin{array}{l}\text { Plot } \\
\text { area } \\
\text { (ha) }\end{array}$ & $\begin{array}{l}\text { Growth } \\
\text { level }\end{array}$ & $\begin{array}{l}\text { Dominance } \\
\left(\mathrm{m}^{2} / \mathrm{ha}\right)\end{array}$ & $\begin{array}{l}\text { Density } \\
\text { (individual/ha) }\end{array}$ & Frequency \\
\hline \multirow{4}{*}{ Timur } & \multirow{2}{*}{$\begin{array}{l}\text { Dolok Sipirok } \\
\text { Reserve (NR) }\end{array}$} & \multirow{2}{*}{2.16} & Tree & 21.16 & 261.57 & 7.81 \\
\hline & & & Pole & 7.81 & 492.59 & 4.06 \\
\hline & \multirow{2}{*}{ Buffer Zone } & \multirow{2}{*}{1.92} & Tree & 12.36 & 186.46 & 6.27 \\
\hline & & & Pole & 7.46 & 529.17 & 4.25 \\
\hline \multirow{4}{*}{ Barat } & \multirow{2}{*}{$\begin{array}{l}\text { Dolok Sibual-buali Nature } \\
\text { Reserve (NR) }\end{array}$} & \multirow{2}{*}{2.16} & Tree & 19.31 & 194.44 & 5.57 \\
\hline & & & Pole & 6.62 & 416.67 & 3.17 \\
\hline & \multirow{2}{*}{ Buffer Zone } & \multirow{2}{*}{5.52} & Tree & 11.81 & 156.34 & 4.36 \\
\hline & & & Pole & 6.39 & 405.07 & 2.94 \\
\hline
\end{tabular}

Table 2. Importance value index (IVI) of three dominant species in each habitat block

\begin{tabular}{|c|c|c|c|c|c|c|c|c|}
\hline \multicolumn{9}{|c|}{ A. East Block } \\
\hline \multirow{2}{*}{ Site } & \multirow{2}{*}{$\begin{array}{c}\text { Growth } \\
\text { levels }\end{array}$} & \multirow{2}{*}{ No } & \multirow{2}{*}{ Local name } & \multirow{2}{*}{ Scientific name } & RD & RDe & RF & IVI \\
\hline & & & & & (\%) & (\%) & (\%) & (\%) \\
\hline \multirow{6}{*}{$\begin{array}{l}\text { Dolok } \\
\text { Sipirok } \\
\text { Nature } \\
\text { Reserve } \\
(n=54)\end{array}$} & \multirow{3}{*}{ Tree } & 1 & Hayun dolok & Syzygium sp. & 8.57 & 9.03 & 8.06 & 25.65 \\
\hline & & \multirow{2}{*}{$\begin{array}{l}2 \\
3\end{array}$} & \multirow{2}{*}{$\begin{array}{l}\text { Mayang } \\
\text { Hoteng turi- } \\
\text { turi }\end{array}$} & Palaquium gutta Burch & 8.92 & 7.61 & 7.35 & 23.88 \\
\hline & & & & Quercus lineata Blume & 9.28 & 4.60 & 4.98 & 18.85 \\
\hline & \multirow{3}{*}{ Pole } & 1 & Hayun dolok & Syzygium sp. & 12.09 & 11.65 & 11.41 & 35.16 \\
\hline & & 2 & Modang & Litsea firma (BI.) Hook. Fil. & 9.04 & 6.39 & 5.94 & 21.36 \\
\hline & & 3 & Mayang & Palaquium gutta Burch & 7.28 & 7.14 & 6.85 & 21.27 \\
\hline \multirow{6}{*}{$\begin{array}{l}\text { Buffer } \\
\text { Zone } \\
(n=48)\end{array}$} & \multirow{3}{*}{ Tree } & 1 & Hayun dolok & Syzygium sp. & 4.37 & 5.87 & 5.98 & 16.22 \\
\hline & & 2 & $\begin{array}{l}\text { Hoteng } \\
\text { maranak }\end{array}$ & $\begin{array}{l}\text { Lithocarpus } \\
\text { conocarpus (Oudem.) Rehder }\end{array}$ & 6.41 & 3.63 & 3.65 & 13.70 \\
\hline & & 3 & Durian & Durio zibethinus Murray & 3.74 & 4.75 & 4.65 & 13.14 \\
\hline & \multirow{3}{*}{ Pole } & 1 & Hayun dolok & Syzygium sp. & 9.16 & 7.99 & 8.13 & 25.28 \\
\hline & & 2 & Mayang & Palaquium gutta Burch & 3.04 & 4.56 & 4.78 & 12.39 \\
\hline & & 3 & Durian & Durio zibethinus Murray & 3.84 & 4.56 & 3.83 & 12.23 \\
\hline
\end{tabular}

B. West (South) Block

\begin{tabular}{|c|c|c|c|c|c|c|c|c|}
\hline Site & $\begin{array}{l}\text { Growth } \\
\text { levels }\end{array}$ & No & Local name & Scientific name & $\begin{array}{l}\text { RD } \\
\text { (\%) }\end{array}$ & $\begin{array}{l}\text { RDe } \\
\text { (\%) }\end{array}$ & $\begin{array}{l}\text { RF } \\
(\%)\end{array}$ & $\begin{array}{l}\text { IVI } \\
(\%)\end{array}$ \\
\hline \multirow{6}{*}{$\begin{array}{l}\text { Dolok } \\
\text { Sibual- } \\
\text { buali } \\
\text { Nature } \\
\text { Reserve } \\
(n=54)\end{array}$} & \multirow{3}{*}{ Tree } & 1 & Hayun Horsik & Ilex pleiobrachiata Loes & 8.00 & 5.71 & 4.65 & 18.36 \\
\hline & & 2 & Hayun Dolok & Syzygium sp. & 4.71 & 7.38 & 5.98 & 18.07 \\
\hline & & 3 & Dori & $\begin{array}{l}\text { Syzygium cf. lineatum (DC.) } \\
\text { Merr.\&Perr. }\end{array}$ & 7.81 & 3.81 & 3.65 & 15.28 \\
\hline & \multirow{3}{*}{ Pole } & 1 & Hayun dolok & Syzygium sp. & 9.89 & 10.22 & 8.77 & 28.88 \\
\hline & & 2 & Hoteng batu & Lithocarpus maingayi (Benth.) & 6.07 & 5.78 & 6.43 & 18.28 \\
\hline & & 3 & Hayun Horsik & Ilex pleiobrachiata Loes & 4.67 & 4.44 & 3.51 & 12.62 \\
\hline \multirow{6}{*}{$\begin{array}{l}\text { Buffer } \\
\text { Zone } \\
(n=48)\end{array}$} & \multirow{3}{*}{ Tree } & 1 & Karet & Hevea brasiliensis Muell Arg & 11.76 & 15.18 & 7.32 & 34.26 \\
\hline & & 2 & Aren & Arenga pinnata Merr & 10.29 & 10.20 & 8.49 & 28.97 \\
\hline & & 3 & Durian & Durio zibethinus Murray & 10.85 & 9.15 & 7.15 & 27.16 \\
\hline & \multirow{3}{*}{ Pole } & 1 & Karet & Hevea brasiliensis Muell Arg & 17.24 & 18.42 & 9.85 & 45.52 \\
\hline & & 2 & Durian & Durio zibethinus Murray & 7.50 & 6.44 & 4.93 & 18.86 \\
\hline & & 3 & Hayun dolok & Syzygium sp. & 3.83 & 4.11 & 4.19 & 12.13 \\
\hline
\end{tabular}

Remarks : RD=(Relative Dominance), $\mathrm{RDe}=($ Relative Density), $\mathrm{RF}=$ Relative Frequency

The highest value of density, frequency, and dominance in tree and pole levels was found in the Eastern Block (Dolok Sipirok NR) because the site was dominated by primary and secondary forests. Large diameter plants, such as atturmangan (Casuarina sumatrana), meranti (Shore sp.), and hoteng/pasang (Lithocarpus sp.) were found in this area. These species in sub-Montane forests can grow above $100 \mathrm{~cm}$ in diameter and spread in the eastern part of the Batang Toru Landscape 
(Simorangkir, 2009). The plant density at the pole was higher than at the tree at each location, especially in the secondary forests. The highest frequency values were found at the tree level, both in the East Block and in the West (South) Block.

Vegetation at the tree level $(\mathrm{dbh}>20 \mathrm{~cm})$ were more evenly distributed across the research plots in the nature reserves and buffer zones. The frequency and dominance of plants at the pole level were low because the vegetation in the buffer zones were dominated by community crops (plants cultivated by farmers, such as rubber, coffee, banana, and cocoa). In buffer zones, such as those on cultivated lands, the community had also cut down large-diameter trees and replaced them with crops that were more suitable for the existing climatic conditions and were of higher economic value. Human land management could affect changes in vegetation composition because the nutrients, soil pH, and sunshine entering the soil surface would be different from those in natural forests (Oliveira et al., 2019; Strubelt et al., 2019).

The dominant vegetation compositions in the two habitat blocks were a little different. In the Dolok Sipirok Nature Reserve (East Block), hayun dolok/forest wood (Syzygium sp.), mayang (Palaquium gutta), and modang (Litsea firma) were of high IVIs, while the Dolok Sibualbuali Nature Reserve was dominated by hayun horsik/horsik wood (Ilex pleiobrachiata) and dori (Syzygium cf. lineatum). In the buffer zones (East Block), in addition to natural vegetation, another species that dominated the landscape was durian, while in the West Block, rubber and sugar palm were more common. Rubber plantations in the Eastern Block were generally included in the sampling (diameter $<10 \mathrm{~cm}$ ) but did not dominate as in the West Block.

Communities around the Sibual-buali Nature Reserve have been clearing land for rubber cultivation for decades, such as those in Bulu Mario, Sealaman, and Sugi Villages. The villages with altitudes of less than $800 \mathrm{~m}$ above sea level and average temperature of $25-29^{\circ} \mathrm{C}$ made them more suitable for rubber development compared to the villages around the Dolok Sipirok Nature Reserve (Kuswanda, 2014; Hazir et al., 2019). Climate differences, land clearing, logging, agroforestry and monoculture land patterns had influenced the composition of plants remaining in the landscape (Strubelt et al., 2019; Jiang et al., 2020).

The difference in the vegetation compositions between blocks was thought to have influenced the lives and populations of orangutans. Orangutan populations in the Eastern Block was lower than that in the West Block (Kuswanda et al., 2020; Ministry of Environment and Forestry, 2019). Orangutans would move to habitats that provided forage plants, especially fruits, even if they were available in the community's cultivated lands (Hockings and Humle, 2010). The dominant vegetation in the Eastern Block was generally not a food source for orangutans. The composition of the vegetation in the two habitat blocks that are still high are estimated to be able to support the needs of orangutans. However, the increase in community plants consumed by orangutans has resulted in the eviction and even hunting of orangutans, especially those found in the buffer zone. When conflict occurs, orangutans will lose, and this threatens the potential growth of orangutans (Wich et al., 2016; Scanes, 2018).

\subsubsection{Species Diversity and Abundance Index}

We found that in both habitat blocks the diversity of plant species in the conservation forests was lower than that in the buffer zones (Figure 3). In conservation forests, plants are more dominated by species that can adapt to environmental conditions, such as hoteng, modang, and mayang. In the buffer zone, species are more diverse because some of them are community plants that are maintained so that they are difficult to find in conservation forests, such as cacao, salak, and jackfruit (Artocarpus heterophyllus Lamk.). The highest $\mathrm{H}^{\prime}$ (Shannon Weaver index) in the West Block (South) at the tree reached 3.99 (East Block), and at the pole level 3.88. The buffer zones had a higher value because they were a mixed habitat type of natural vegetation and cultivated crops. Various species of community cultivation plants were not found in the nature reserve. The existence of human activities will affect changes in species diversity and plant community structure in a 
landscape. Low-level disturbances, such as reduction of replacement of trees by cultivated plants, can increase the species diversity in a community's land and support tree regeneration (Sandel, 2015; Dell et al., 2019). We found that forests that were dominated by medang, hoteng, atturmangan, and incense (Styrax benzoin Dryand) had been replaced by rubber, coffee, and cinnamon plants, such as in Bulu Mario and Aek Batang Paya villages.
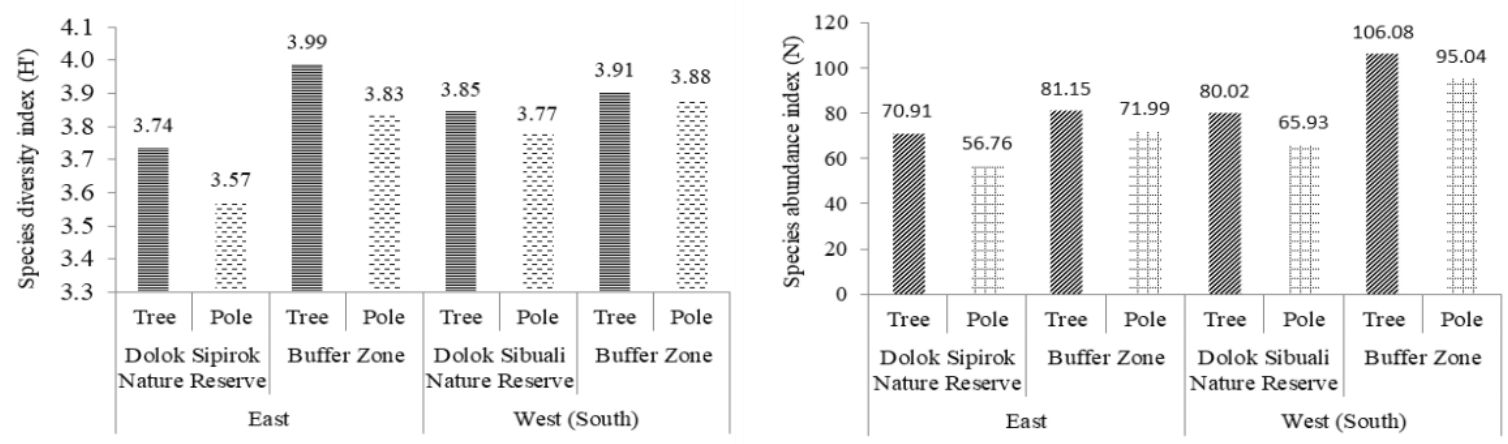

Figure 3. The species diversity and abundance index in each habitat block

The species diversity index included a high category with $\mathrm{H}^{\prime}$ between 3 and 4, meaning that the habitat conditions of the orangutans were stable if there were no disturbances and land changes on a large scale (Willie et al., 2012). The high species diversity in the vegetation in the community lands would form a complex relationship between its elements (more stable ecosystems) and have higher resistance to disturbances compared to monoculture plants (Seddon et al., 2016). The diverse species could help balance the functioning of the ecosystems and the process of decomposition to provide soil nutrients in tropical forests (Willis et al., 2018; Oliveira et al., 2019).

The species abundance indices $(\mathrm{N})$ showed that the West (South) Block was higher in value than the East Block. The highest $\mathrm{N}$ value found at the tree and pole levels in the Sibual-buali Nature Reserve was 106.08. High species abundance could be influenced by high plant densities in the buffer zones, especially in the mixed garden and monoculture. The abundance of species in a habitat could vary and change based on space and time scales due to the introduction of exotic species (Frieswyk et al., 2007; Dell et al., 2019), such as, rubber and coffee which were cultivated by the people in the Batang Toru Landscape. Coffee and rubber are planted by the community in a monoculture manner in the orangutan habitat so that the orangutan's trajectory moves to agroforestry land that provides trees with a tight and close crown. The orangutan's focus on agroforestry land has resulted in a high conflict with landowners. The farmer crops have been damaged and the fruit consumed by orangutans, include valuable ones to the community, such as durian, petai, and sugar palm.

\subsection{Orangutan Food Species}

The observation found 80 species from 30 families or $53.7 \%$ of all species. The most abundant species included the families Lauraceae and Moraceae (11 species), Fagaceae (8 species), and Sapotaceae (7 species), such as asam hing (Dracontomelon dao (Blanco) Merr. \& Rolfe), bayur (Pterospermum blumeanum Korth.), and gumbot (Ficus toxicaria Linn). In a previous study, Kuswanda (2014) mentioned that feed plants in Sibual-buali Nature Reserve were of 61 species, and in Dolok Sipirok Nature Reserve 55 species. There was a species of feed plant in the buffer zones which was not available in the nature reserves, such as nangka (Artocarpus heterophyllus Lamk.), jambu air (Syzygium aqueum (Burm. F), deke-deke (Ixonanthes petiolaris Blume). Orangutans would move to look for habitats with abundant fruit production (Marshall et al., 2009). The orangutan feed plants in Batang Toru Landscape were identified to belong to 191 species of 46 families (Haryanto et 
al., 2019). The complete names of species, families, and parts of plants consumed by orangutans are presented in Appendix 1.

The highest portion of feed plants consumed by orangutans was composed of only fruits $(35.00 \%)$, followed by only leaves $(30.00 \%)$, fruits and leaves $(17.50 \%)$, and fruits, leaves, and bark (13.75\%) (see Figure 4 and Appendix 1). Orangutans were also observed to consume 'umbut' (i.e., the white part at the base of leaves or the tip of the stem which is soft in pandanus and rattan species). The fruits consumed by orangutans reached a portion of $68.75 \%$, almost the same as the portion found by Wich et al. (2014) (73.3\%). Plants that were eaten by orangutans were generally of the family Moraceae. The species of Moraceae have soft flesh (Roth et al., 2020) and white gummy materials (Meijaard et al., 2001), which is highly favored by orangutans, such as gumbot (Ficus toxicaria), cempedak (Arthocarpus integler), and dongdong (Ficus ribes).

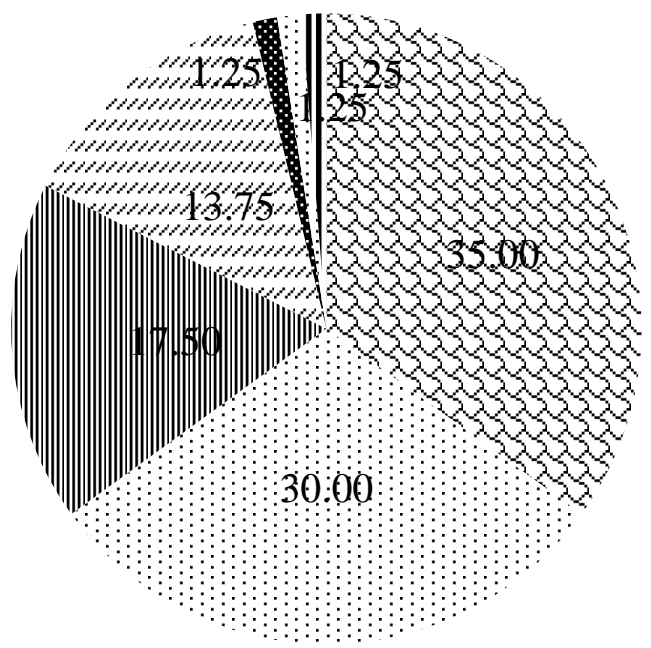

$\therefore$ Only Fruit

$\therefore$ Only Leaves

IIII Fruit and Leaves

»Fruit, Leaves and Bark

Fruit and Umbut

Fruit and Flowers

III Leaves and Bark

Figure 4. Percentage of plant parts consumed by orangutans

Previous studies found that orangutans consume fruits more frequently than other plant parts, and sometimes they feed on ants, insects, and honey (Atmoko et al., 2014; Wich et al., 2014; Roth et al., 2020). Orangutans consume fruit of 1-25 species every day. When the fruit season recedes, the orangutans will consume more leaves. There are $5-30 \%$ of species that produce fruit as feed each month (Sugardjito et al., 1987). In the East Block, 52.27-60.38\% of species provided feed, and in the West (South) block 51.65-64.52\%. Higher feed potential in the West Block indicates that feed for orangutans was evenly distributed, based on both the forest status and growth rate. In the West (South) Block, there were more feed plants because many plants were cultivated by the community as orangutan feed, such as, durian, petai, and sugar palm. In some of the observation sites, orangutans were found to consume rubber leaves even though they are not a natural food for orangutans.

Orangutans often visited the community lands (buffer zones) when the fruit season in the nature reserve neared to an end. We found six orangutans in community lands during the durian and petai seasons, from October to February. The community expelled the orangutans because these orangutans were considered to have disturbed and damaged their plants. On the other hand, forest degradation had made it difficult for orangutans to return to nature reserves. Their home ranges had been cleared, and as a result they must survive in habitats that threaten them. In habitats with low plant density (open lands), orangutans will be easily found, expelled, and even hunted by humans (Hockings and Humle, 2010; Wich et al., 2014).

Orangutans tend to forage for their own food and do not form social groups even when the fruit feed is abundant (Roth, 2020). The Tapanuli orangutan will spread out for food and maintain a 
distance between them of more than $1 \mathrm{~km}$ to avoid competition for food with other individuals and the potential for rape by adult males (Meijaard et al., 2001; Kanamori et al., 2017). This results in the orangutans breaching into more extensive community lands to get enough forage plants. Potential damage to plants will increase and trigger conflicts around the nature reserve because people still rely on agricultural and forest products in their villages as their source of income. This causes barriers on the efforts to minimize human and orangutan conflicts and increases threats to the lives of orangutans (Kuswanda, 2014; Uddin et al., 2020; Siljander et al., 2020).

\subsection{Estimated Habitat Carrying Capacity}

The assessment of carrying capacity can be approached by measuring the available feed productivity per hectare that can be utilized by wildlife (Ismail and Jiwan, 2015; Chapman and Byron, 2018; Alikodra, 2019). Kuswanda and Bismark (2007) state that the productivity of leaves of orangutan feed plants around the Dolok Sibual-bulai Nature Reserve was $40.66 \mathrm{~kg} / \mathrm{ha}$ per day (wet weight) or $14.74 \mathrm{~kg} / \mathrm{ha}$ per day (dry weight). Fruit productivity was $43.6 \mathrm{~kg} / \mathrm{ha}$ per day (wet weight) or $18.6 \mathrm{~kg} /$ ha per day (dry weight). During the fruit season, fruit productivity averaged around 7.63 $\mathrm{kg} / \mathrm{ha}$ per day (wet weight) or $3.23 \mathrm{~kg} / \mathrm{ha}$ per day (dry weight) (Sugardjito et al., 1987).

We used several correction factors in the carrying capacity analysis to get more realistic values: 1) potential habitat for orangutans by considering the existence of gardens, farms, and agricultural and human activities (0.33) (Rockwood, 2006; Alikodra, 2019); 2) the percentage of habitat that can be significantly utilized by orangutans of the entire habitat area (0.36) (Meijaard et al., 2001); 3) the amount of each food consumed (0.556 for fruit and 0.353 for leaves) (Sinaga, 1992); 4) the percentage of time to consume food ( 0.6 for fruit and 0.25 for leaves) (Meijaard et al., 2001); 5) the correction factor for undesirable foods, falls, and other causes (0.5) (Alikodra, 2019); and 6) orangutan consumption (10\% of body weight) (Alikodra, 2019), which was an average of $6.2 \mathrm{~kg} / \mathrm{day}$ per individual (Kuswanda and Bismark, 2007).

The estimated habitat carrying capacity for orangutans in the Batang Toru Landscape, South Tapanuli Regency, in the area of 29,192 ha (Kuswanda et al., 2020) was analyzed involving 247 (224$269)$ individuals, covering 99 (89-108) individuals in the East Block and 148 (135-161) individuals in the West (South) Block. However, consideration was not taken of the competition for food sources and space with other primate species, such as, siamang (Symphalangus syndactylus) and southern pigtail macaque (Macaca nemestrina). A preliminary estimate though it is, this value can be a starting point for developing conservation programs, given the lack of information about the Tapanuli orangutans.

The carrying capacity of the West Block was greater because in the buffer zones there were feed plants cultivated by the community, and because the habitat there was more extensive compared to that in the East Block. The high carrying capacity value will give a greater hope that the orangutan population can further develop. The orangutan population in the conflict area in Batang Toru Landscape, South Tapanuli Regency, was estimated to consist of 155 (121-187) individuals (Kuswanda et al., 2020). The wildlife population will grow and reflect the value of its carrying capacity (Alikodra, 2019). However, to increase the population of orangutans, habitat management is needed so that the case of human-orangutan conflict can be minimized in the Batang Toru Lansekap.

\subsection{Implications for Habitat Management in Mitigation of Human-Tapanuli Orangutan Conflict}

Mitigating human-orangutan conflict is a process, which is underpinned by efforts to resolve or reduce conflicts by aligning human interests without sacrificing safety for orangutans. The implementation of conflict mitigation must pay attention to the principles that humans and wildlife have an equally important and mutually reinforcing role. This can be bolstered by reducing the risk of economic losses to humans and further supported by preserving wildlife involved in the conflict, which certainly applies for the case of the Tapanuli orangutan (Ministry of Forestry, 2014). The 
conflict between humans and Tapanuli orangutans is thought to have increased due to the reduction in primary forest areas converted to plantations, especially with growing monoculture patterns toward coffee, rubber, and oil palm, both in the East and West (South) Blocks. With deforestation, orangutans will move to safer habitats and seek out more abundant composition of vegetation and forage plants (Bastian et al., 2012; Hardus et al., 2012; Haryanto et al., 2019).

One of the efforts to minimize human-orangutan conflict is through habitat management (Hockings \& Humle, 2010; Atmoko, 2014; Alikodra, 2019). Habitat components, such as vegetation composition and diversity, can affect population growth. The orangutan population will also develop if the food is adequate and the habitat is not disturbed by human activity (Russon, 2010; Meijaard et al., 2018; Pandong et al., 2019). The results of the research have proven that the orangutan population is under the carrying capacity of the habitat due to the high human activity in the habitat of the Tapanuli orangutan, such as gardening and taking sap water, namely the local tradition of "harvesting sap water" from palm trees (Arenga pinnata) in the orangutan habitat.

The implications of habitat management recommended in mitigating human-tapanuli orangutan conflict are increasing patrols involving the community to monitor habitat destruction and orangutan populations in conservation forests by the Center for Conservation of Forest Resources in North Sumatera in collaboration with village institutions. In addition, it would be helpful to conduct habitat enrichment with forage plants in the Forest Management Unit area as a natural barrier for orangutans, to be supported under the North Sumatra Government, which can help to facilitate the cultivation of plants that are not a source of orangutan food on community lands. Another program that needs to be developed is to integrate a corridor development plan between conservation forests and buffer areas. Corridors are very important because human activities and land use will determine the home ranges of animals due to fragmentation (Tscharntke et al., 2012; Hawn et al., 2018) from the development of plantations/monocultures and settlements (Pliscoff et al., 2020). Corridor development can be conducted through enrichment of orangutan food species on fruits that are not used by humans and have wide crowns, such as beringin (Ficus benjamina Linn.), hoteng dori (Lithocarpus endeisocarpus (Korth.) A. Camus, and meranti (Shorea gibbosa Brandis).

\section{Conclusion}

Characteristics of land cover types in orangutan habitat include primary and secondary forests, agroforestry land, monoculture gardens, and community fields. Vegetation species were identified at 149 species from 46 families, consisting of 101 species (36 families) in the East Block, and 136 species (44 families) in the West Block. The vegetation species, dominance, density, and frequency were higher in the East Block but were higher for forage plants in the West Block. The diversity and abundance of vegetation in the buffer zone are higher with the discovery of community plant species such as durian (Durio zibethinus), petai (Parkia speciosa), and aren (Arenga pinnata). The feed plants identified, included 80 species from 30 families, and the highest parts of those consumed by orangutans were fruit (35.00\%) and leaves (30.00\%). The large number of cultivated plants that are used as food for orangutans was a trigger for conflict with humans, especially on agroforestry lands and mixed gardens. Habitat potential for the area can support an increase in the orangutan population to 247 individuals if the potential for conflict can be minimized. Habitat management in mitigating human-Tapanuli orangutan conflict is recommended through patrols for the protection of conservation forests and monitoring for orangutans, enriching habitat with orangutan food, cultivating non-feed crops on community lands, and building corridors with plants eaten by orangutans between conservation forests and buffer areas.

\section{Conflict of Interest}

We declare no conflict of interest for the undertaking of this research and in the publication process. 


\section{Acknowledgments}

The authors would like to thank the University of Sumatera Utara, the Center for Conservation of Forest Resources in North Sumatera, and the Environmental and Forestry Research and Development Institute of Aek Nauli. Acknowledgments are also extended to forest police officers and the Batang Toru community assisted with the research.

Appendix 1. Species and plant parts consumed by orangutans in South Tapanuli

\begin{tabular}{|c|c|c|c|c|}
\hline No & Scientific name & Local name & Family & $\begin{array}{l}\text { The part } \\
\text { consumed by } \\
\text { orangutans }\end{array}$ \\
\hline 1 & $\begin{array}{l}\text { Actinodaphne glabra Blume } \\
\text { Alseodaphne peduncularis }\end{array}$ & $\begin{array}{l}\text { Jungjung buit } \\
\text { Modang }\end{array}$ & Lauraceae & Fruit, Leaves \\
\hline 2 & (Wall. ex Nees) Meisn & jantan & Lauraceae & Leaves, Bark \\
\hline 3 & Aporusa lunata ( Miq.) Kurz. & $\begin{array}{l}\text { Hoteng } \\
\text { harakas }\end{array}$ & Euphorbiaceae & Fruit \\
\hline 4 & $\begin{array}{l}\text { Aquilaria malaccensis Lamk. } \\
\text { Archidendron bubalinum (Jack) }\end{array}$ & Songgak & Thymelaeaceae & Leaves \\
\hline 5 & I.C. Nielsen & Habo & Mimosasae & Fruit, Leaves \\
\hline 6 & $\begin{array}{l}\text { Archidendron jeringa (Jack) } \\
\text { I.C.Nielsen }\end{array}$ & Jengkol & Mimosasae & Fruit, Leaves, Bark \\
\hline 7 & Arenga pinnata Merr & Aren & Palmae & Fruit, Umbut \\
\hline 8 & $\begin{array}{l}\text { Arthocarpus integler (Thunb). } \\
\text { Merr. }\end{array}$ & Cempedak & Moraceae & Fruit, Leaves, Bark \\
\hline 9 & $\begin{array}{l}\text { Artocarpus elasticus Reinw. Ex } \\
\text { Bl. }\end{array}$ & Torop & Moraceae & Fruit, Bark, Leaves \\
\hline 10 & Artocarpus gomegianus Trec. & $\begin{array}{l}\text { Akkorodan/ru } \\
\text { bai }\end{array}$ & Moraceae & Fruit, Leaves, Bark \\
\hline 11 & Lamk. & Nangka & Moraceae & Fruit, Leaves, Bark \\
\hline 12 & Artocarpus rigidus Blume & Hatopul & Moraceae & Fruit, Leaves, Bark \\
\hline 13 & Baeckea frutescens Linn & Game Game & Myrtaceae & Fruit, Leaves \\
\hline 14 & Calophyllum soulattri Burm. Fil. & Bittangur & Guttiferae & Fruit \\
\hline 15 & $\begin{array}{l}\text { Castanopsis inermis (Lindl.) } \\
\text { Benth. \& Hook.f. }\end{array}$ & $\begin{array}{l}\text { Hoteng } \\
\text { Barangan }\end{array}$ & Fagaceae & Fruit \\
\hline 16 & $\begin{array}{l}\text { Castanopsis tungurrut (Blume) } \\
\text { A.DC. }\end{array}$ & Andihit & Fagaceae & Fruit \\
\hline 17 & $\begin{array}{l}\text { Cinnamomum iners Reinw. Ex } \\
\text { Blume } \\
\text { Cinnamomum porectum }\end{array}$ & $\begin{array}{l}\text { Modang } \\
\text { sabal }\end{array}$ & Lauraceae & Leaves \\
\hline 18 & (Roxb.) Kosterm & Losa & Lauraceae & Fruit, Leaves \\
\hline 19 & $\begin{array}{l}\text { Cryptocarya nitens (BI.) Koord. } \\
\text { \& Valeton }\end{array}$ & $\begin{array}{l}\text { Rambutan } \\
\text { hutan }\end{array}$ & Lauraceae & Fruit, Leaves \\
\hline 20 & Dipterocarpus gracilis Blume & Lajo Lajo & Dipterocarpaceae & Leaves \\
\hline 21 & $\begin{array}{l}\text { Dracontomelon dao (Blanco) } \\
\text { Merr. \& Rolfe }\end{array}$ & Asam Hing & Anacardiaceae & Fruit \\
\hline 22 & Durio zibethinus Murray & Durian & Malvaceae & Fruit, Flower \\
\hline 23 & $\begin{array}{l}\text { Eugenia grandis Wight ex } \\
\text { Walp. }\end{array}$ & $\begin{array}{l}\text { Hayun Dolok } \\
\text { Jambu }\end{array}$ & Myrtaceae & Fruit, Leaves \\
\hline
\end{tabular}




\begin{tabular}{|c|c|c|c|c|}
\hline No & Scientific name & Local name & Family & $\begin{array}{l}\text { The part } \\
\text { consumed by } \\
\text { orangutans }\end{array}$ \\
\hline 24 & Eurea acuminata A.P.DC. & Tambiski & Theaceae & Fruit \\
\hline 25 & Ficus altissima Bl. & Attahasi & Moraceae & Fruit, Leaves, Bark \\
\hline 26 & Ficus benjamina Linn. & Beringin & Moraceae & Fruit, Leaves, Bark \\
\hline 27 & Ficus bistipulata Griff. & Andarasi & Moraceae & Fruit, Leaves, Bark \\
\hline 28 & Ficus drupacea Thunb. & Rao & Moraceae & Fruit \\
\hline 29 & Ficus geocarpa Teijsm. ex Miq. & Rube & Urticaceae & Fruit, Leaves \\
\hline 30 & Ficus ribes Reinw. Ex Bl. & Dongdong & Moraceae & Fruit, Leaves, Bark \\
\hline 31 & $\begin{array}{l}\text { Ficus toxicaria Linn } \\
\text { Flacourtia rukam, Zoll. \& }\end{array}$ & Gumbot & Moraceae & Fruit, Leaves, Bark \\
\hline 32 & Moritzi & Rukam & Flacourtiaceae & Leaves \\
\hline 33 & Garcinia cf bancana Linn. & Holemisa & Guttiferae & Fruit \\
\hline 34 & Garcinia dioica Blume & Handis & Guttaceae & Fruit \\
\hline 35 & Glochidion sp. & Motton & Euphorbiaceae & Leaves \\
\hline 36 & $\begin{array}{l}\text { Hancea subpeltata (Blume) } \\
\text { Kulju \& Welzen }\end{array}$ & Poga-poga & Euphorbiaceae & Fruit Leaves \\
\hline 37 & Hevea brasiliensis Muell Arg & $\begin{array}{l}\text { Karet } \\
\text { Simarloba- }\end{array}$ & Euphorbiaceae & Leaves \\
\hline 38 & Hymenodictyon orixense Mabb & $\begin{array}{l}\text { loba/bosi- } \\
\text { bosi }\end{array}$ & Rubiaceae & Leaves \\
\hline 39 & Ixonanthes petiolaris BI. & Pege-pege & Linnaceae & Fruit \\
\hline 40 & Ixonanthes petiolaris Blume & Dede-deke & Linnaceae & Fruit \\
\hline 41 & Knema conferta Warb & Darodong & Myristicaceae & Fruit \\
\hline 42 & Lansium domesticum Correa & Langsa hutan & Meliaceae & Fruit, Leaves \\
\hline 43 & $\begin{array}{l}\text { Lithocarpus } \\
\text { conocarpus (Oudem.) Rehder }\end{array}$ & $\begin{array}{l}\text { Hoteng } \\
\text { Maranak }\end{array}$ & Fagaceae & Fruit \\
\hline 44 & $\begin{array}{l}\text { Lithocarpus endeisocarpus } \\
\text { (Korth.) A. Camus } \\
\text { Lithocarpus hystrize (Korth.) }\end{array}$ & $\begin{array}{l}\text { Hoteng } \\
\text { dori/gori }\end{array}$ & Fagaceae & Fruit \\
\hline 45 & Rehd & Hoteng & Fagaceae & Fruit \\
\hline 46 & $\begin{array}{l}\text { Lithocarpus maingayi (Benth.) } \\
\text { Rehder } \\
\text { Lithocarpus }\end{array}$ & Hoteng Batu & Fagaceae & Fruit \\
\hline 47 & $\begin{array}{l}\text { pseudomoluccus (Blume) } \\
\text { Rehder }\end{array}$ & $\begin{array}{l}\text { Hoteng } \\
\text { Bunga }\end{array}$ & Fagaceae & Fruit \\
\hline 48 & Litsea firma (BI.) Hook. Fil. & Modang & Lauraceae & Fruit \\
\hline 49 & $\begin{array}{l}\text { Litsea grandis (Wall. Ex Nees) } \\
\text { Hook. Fil. }\end{array}$ & $\begin{array}{l}\text { Modang } \\
\text { Jambu }\end{array}$ & Lauraceae & Fruit \\
\hline 50 & Litsea odorifera Valeton & $\begin{array}{l}\text { Modang } \\
\text { Hunik } \\
\text { Modang }\end{array}$ & Lauraceae & Fruit \\
\hline 51 & Litsea resinosa Blume & $\begin{array}{l}\text { Lendir } \\
\text { Modang }\end{array}$ & Lauraceae & Leaves \\
\hline 52 & Litsea robusta Blume & pokat & Lauraceae & Leaves \\
\hline 53 & Litsea robusta Blume & Modang rata & Lauraceae & Leaves \\
\hline
\end{tabular}




\begin{tabular}{|c|c|c|c|c|}
\hline No & Scientific name & Local name & Family & $\begin{array}{l}\text { The part } \\
\text { consumed by } \\
\text { orangutans }\end{array}$ \\
\hline 54 & $\begin{array}{l}\text { Macaranga gigantea (Rchb.f. } \\
\text { \& Zoll.) Müll.Arg. }\end{array}$ & Sapot & Euphorbiaceae & Leaves \\
\hline 55 & $\begin{array}{l}\text { Madhuca laurifolia (King \& } \\
\text { Gamble) H.J.Lam }\end{array}$ & Balam & Sapotaceae & Leaves \\
\hline 56 & Mangifera quadrifida Jack & Bacang hutan & Anacardiaceae & Fruit \\
\hline 57 & Myrtistica iners Blume & Dara Dara & Myristicaceae & Fruit \\
\hline 58 & Palaquium gutta Burch & Mayang & Sapotaceae & Leaves \\
\hline 59 & Palaquium rostratum Burck. & $\begin{array}{l}\text { Mayang padi } \\
\text { Mayang }\end{array}$ & Sapotaceae & Leaves \\
\hline 60 & Palaquium sumatranum Burck. & Durian & Sapotaceae & Leaves \\
\hline 61 & Parkia speciosa Hassk. & Petai & Leguminosae & Fruit \\
\hline 62 & Payena glabra H.J & Mayang Rata & Sapotaceae & Leaves \\
\hline 63 & $\begin{array}{l}\text { Payena leerii (Teijsm.\&Binn.) } \\
\text { Kurz. }\end{array}$ & Mayang batu & Sapotaceae & Leaves \\
\hline 64 & Payena sericea H.J. LAM & $\begin{array}{l}\text { Mayang } \\
\text { bulan }\end{array}$ & Sapotaceae & Leaves \\
\hline 65 & Pentaphllax malayana Ridl. & $\begin{array}{l}\text { Modang siak- } \\
\text { siak }\end{array}$ & Pentaceae & Leaves \\
\hline 66 & Podocarpus imbricatus BI. Var & Sampinur & Podocarpaceae & Leaves \\
\hline 67 & Pometia pinnata Forst \& Forst & Matoa/hase & $\underline{\text { Sapindaceae }}$ & Fruit \\
\hline 68 & $\begin{array}{l}\text { Pternandra cf. Tuberculata } \\
\text { (Korth.) Nayar } \\
\text { Pterospermum blumeanum }\end{array}$ & Baja & Melastomataceae & Fruit \\
\hline 69 & Korth. & Bayur & Sterculiaceae & Fruit, Leaves \\
\hline 70 & Quercus lineata Blume & $\begin{array}{l}\text { Hoteng Turi } \\
\text { Turi }\end{array}$ & Fagaceae & Fruit \\
\hline 71 & Rhodamnia cinerea Jack. & $\begin{array}{l}\text { Hapundung/h } \\
\text { ara moting }\end{array}$ & Myrtaceae & Fruit \\
\hline 72 & Santiria rubigiosa Bl.,var. & $\begin{array}{l}\text { Simar gala- } \\
\text { gala }\end{array}$ & Burseraceae & Fruit \\
\hline 73 & Schima wallichii Korth. & Simartolu & Theaceae & Fruit Leaves \\
\hline 74 & Shorea gibbosa Brandis & Meranti & Dipterocarpaceae & Leaves \\
\hline 75 & Shorea lefrosula Miq & $\begin{array}{l}\text { Meranti } \\
\text { Merah }\end{array}$ & Dipterocarpaceae & Leaves \\
\hline 76 & $\begin{array}{l}\text { Shorea hopeifolia (Heim) } \\
\text { Symington }\end{array}$ & Laccat bodat & Dipterocarpaceae & Leaves \\
\hline 77 & Styrax serrulatus Roxb. & Talun & Styraceae & Fruit Leaves \\
\hline 78 & $\begin{array}{l}\text { Syzigium garcinifolia (D.Don) } \\
\text { Hochr. }\end{array}$ & Jambu-jambu & Myrtaceae & Fruit, Leaves \\
\hline 79 & Syzygium aqueum (Burm. F) & Jambu Air & Myrtaceae & Fruit, Leaves \\
\hline 80 & Vitaca micrantha Sloot & Raru & Dipterocarpaceae & Leaves \\
\hline
\end{tabular}

\section{References}

Abram, N. K., Meijaard, E., Wells, J. A., Ancrenaz, M., Pellier, A. S., Runting, R. K., ......, \& Mengersen, K. (2015). Mapping perceptions of species' threats and population trends to inform 
conservation efforts: the Bornean orangutan case study. Diversity and Distributions, 21(5): 487489. https://doi.org/10.1111/ddi.12286

Alatar, A., El-Sheikh, M. A., \& Thomas, J. (2012). Vegetation analysis of Wadi Al-Jufair: a hyper-arid region in Najd, Saudi Arabia. Saudi Journal of Biological Sciences, 19(1), 43-54.

Alikodra, H. S. (2019). Ekologi konservasi pengelolaan satwaliar: hidup harmoni dengan alam. Bogor: PT. Penerbit IPB Press.

Ango, T. G., Borjeson, L., \& Senbeta, F. (2017). Crop raiding by wild mammals in Ethiopia: impacts on the livelihoods of smallholders in an agriculture-forest mosaic landscape. Oryx, 51, 527-537. https://doi.org/10.1017/S0030605316000028

Atmoko, S. S. U, Vilantinus, A., Susilo, H. D., Rifki, M. A., Siregar, P. G., \& Ermayanti. (2014). Panduan mitigasi konflik manusia dan orangutan. Jakarta. Forum Orangutan Indonesia.

Barbour, G. M., Burk, J. K., \& Pitts, W. D. (1987). Terrestrial plant ecology. New York: The Benyamin/Cummings Publishing Company.

Bastian, M. L., van Noordwijk, M. A., \& van Schaik, C. P. (2012). Innovative behaviors in wild Bornean orangutans revealed by targeted population comparison. Behaviour, 149 (3-4), 275-297. https://doi.org/10.1163/156853912X636726

Bookhout, A. (1994). Research and management technique for wildlife and habitat. Ohio: National Biological Service Ohio Cooperation Fish and Wildlife Research, Columbus State University.

BPS-Statistics of South Tapanuli Regency. (2019). Kabupaten Tapanuli Selatan dalam Angka 2019. Sumatera Utara. Indonesia.

Buckley, R. C, Morrison, C., \& Castley, J. G. (2016). Net effects of ecotourism on threatened species survival. PLOS ONE, 11(2). https://doi.org/10.1371/journal.pone.0147988

Chapman, E. J., \& Byron, C. J. (2018). The flexible application of carrying capacity in ecology. Global Ecology and Conservation, 13, e00365. https://doi.org/10.1016/j.gecco.2017.e00365

Córdova-Lepe, F., Valle R. D., \& Jiliberto, R. R. (2018). The process of connectivity loss during habitat fragmentation and their consequences on population dynamics. Ecological Modelling, 376, 6875. https://doi.org/10.1016/j.ecolmodel.2018.01.02

Daniel, G. S., Verburg, P. H., \& Dobrovolski, R. (2020). Habitat loss, extinction predictability and conservation efforts in the terrestrial ecoregions. Biological Conservation, 246. https://doi.org/10.1016/ j.biocon. 2020.108579.

Dell, J. E., Pokswinski, S. M., Richards, L. A., Hiers, J. K., Williams, B., O’Brien, J.J,. ..., \& Dyer, L. A. (2019). Maximizing the monitoring of diversity for management activities: additive partitioning of plant species diversity across a frequently burned ecosystem. Forest Ecology and Management, 432, 409-414. https://doi.org/10.1016/j.foreco.2018.09.022

Dickman, A. J. (2010). Complexities of conflict: the importance of considering social factors for effectively resolving human-wildlife conflict. Animal Conservation 13, 458-466. https://doi.org/10.1111/j.1469-1795.2010.00368.x

Djojoasmoro, R., Simanjuntak, C. N., Galdikas, B. M. F., \& Wibowo, T. (2004). Orangutan distribution in North Sumatera. Jurnal Primatologi Indonesia, 4(1), 2-6.

Fachrul, M. F. (2007). Metode Sampling Bioekologi. Jakarta: Bumi Aksara.

Frieswyk, C. B., Johnston, C. A., \& Zedler, J. B. (2017). Identifying and Characterizing Dominant Plants as an Indicator of Community Condition. Journal of Great Lakes Research, 33, 125-135. https://doi.org/10.3394/0380-1330(2007)33[125:IACDPA]2.0.CO;2

Garcia, C. A., Savilaakso, S., Verburg, R. W., Gutierrez, V., Wilson, S. J., Krug, C. B., Sassen, M., Robinson, B. E., ......, \& Waeber, P.O. (2020). The global forest transition as a human affair. One Earth, 2(5), 417-428. https://doi.org/10.1016/j.oneear.2020.05.002

Geng, S., Shi, P., Song, M., Zong, N., Zu, J., \& Zhu, W. (2019). Diversity of vegetation composition enhances ecosystem stability along elevational gradients in the Taihang Mountains, China. Ecological Indicators, 104, 594-603. https://doi.org/10.1016/j.ecolind.2019.05.038 
Harahap, R. H and Humaizi. (2018). Local wisdom in preservation of Lake Toba ecosystems: study on TobaLake community in the Village of Silalahi I, Sub District of Silahisabungan, Dairi Regency, North Sumatera Province. IOP Conference Series: Earth and Environmental Science, 126, 1-8.

Hardus, M. E., Lameira, A. R., Menken, S. B. J., \& Wich, S. A. (2012). Effectsof logging on orangutan behavior. Biological Conservation, 146, 177-187. https://doi.org/10.1016/j.biocon.2011.12.014

Haryanto, R. P, Rinaldi, D., Arief, H., Soekmadi, R., Kuswanda, W., Chasanatun, F. N.,....\& Simangunsong, Y. D. (2019). The Ecology of Tapanuli Orangutan. Bogor : Working Group of Batang Toru Sustainable Landscape Management Press.

Hawn, C. L., Herrmann, J. D., Griffin, S. R., \& Haddad, N. M. (2018). Connectivity increases trophic subsidies in fragmented landscapes. Ecology Letters, 21, 1620-1628. https://doi.org/10.1111/ele.12958

Hazir, M. H. M., Kadir, R. A., Gloor, E., \& Galbraith, D. 2019. Effect of agroclimaticvariability on land suitability for cultivating rubber (Hevea brasiliensis) and growth performance assessment in thetropical rainforest climate of Peninsular Malaysia. Climate Risk Management, 27. https://doi.org/10.1016/j.crm.2019.100203

Hockings, K., \& Humle, T. (2010). Best Practice Guidelines for the Prevention and Mitigation of Conflict Between Humans and Great Apes. Switzerland: IUCN/SSC Primate Specialist Group.

Indonesian Institute of Sciences (1982). Series Book of Flora Malesiana. Van Steenis, C. G. G. J., \& Nijhoff, E. H. M. (Ed.). London: Junk Publishers.

Indonesian National Standards/SNI (2014). Klasifikasi penutup lahan-bagian 1: skala kecil dan menengah nomor 7645-1. Jakarta: Badan Standardisasi Nasional.

Ismail, D., \& Jiwan, D. (2015). Browsing preference and ecological carrying capacity of sambar deer (Cervus unicolor brookei) on secondary vegetation in forest plantation. Animal Science Journal, 86(2), 225-237. https://doi.org/10.1111/asj.12271

Jiang, H., Xu, X., Guan, M., Wang, L., Huang, Y., \& Jiang, Y. (2020). Determining the contributionsof climate change and human activities to vegetation dynamics in ago-pastural transitional zone of northern Chinafrom 2000 to 2015. Science of the Total Environment, 718. https://doi.org/10.1016/j.scitotenv.2019.134871

Kanamori, T., Kuze, N., Bernard, H., Malim, T. P., \& Kohshima, S. (2017). Fluctuations of population density in Bornean orangutans [Pongo pygmaeus morio Linnaeus] related to fruit availability in the Danum Valley, Sabah, Malaysia: a 10-year record including two mast fruitings and three other peak fruitings. Primates, 58, 225-235. https://doi.org/10.1007/s10329-016-0584-5

Kosmidou, V., Petrou, Z., Bunce, R. G. H., Mücher, C. A., Jongman. R. H. G., Bogers M. B. M, ......, \& Petrou, M. (2014). Harmonization of the Land Cover Classification System (LCCS) with the General Habitat Categories (GHC) classification system. Ecological Indicators, 36, 290-300. doi: https://doi.org/10.1016/j.ecolind.2013.07.025

Kuswanda, W. (2014). Orangutan Batangtoru: kritis di ambang punah. Bogor : Forda Press.

Kuswanda, W., \& Bismark, M. (2007). Daya dukung habitat orangutan (Pongo abelii Lesson) di Cagar Alam Dolok Sibual-buali, Sumatera Utara. Jurnal Penelitian Hutan dan Konservasi Alam IV(1), 095-105.

Kuswanda, W., \& Sugiarti. 2005. Potensi Habitat dan Pendugaan Populasi Orangutan (Pongo abelii Lesson 1827) di Cagar Alam Dolok Sibual-buali. Jurnal Penelitian Hutan dan Konservasi Alam II(6), 555-566.

Kuswanda, W., \& Sunandar A. D. (2019). Analysis of land use change and its relation to land potential and elephant habitat at Besitang Watershed, North Sumatra, Indonesia. Biodiversitas, 20, $350-$ 358. https://doi.org/0.13057/biodiv/d200141

Kuswanda, W., Harahap, R.H., Alikodra, H.S., \& Sibarani, R. (2020). Nest characteristics and populations of Tapanuli Orangutans in Batangtoru Landscape, South Tapanuli District, Indonesia. Biodiversitas, 21, 3398-3408. https://doi.org/0.13057/biodiv/d210765 
Lillo, E. P., Edwino, S. F., \& Lillo, M. J. R. (2019). Plant diversity and structure of forest habitat types on Dinagat Island, Philippines. Journal of Asia-Pacific Biodiversity, 12(1), 83-105. https://doi.org/10.1016/j.japb.2018.07.003

Maldonado, E., Sharma, S., Dutta, T., Wood, C., Panwar, H. S., Seidensticker, J.,...., \& Wood, T.C. (2013). Forest corridors maintain historical gene flow in a tiger metapopulation in the highlands of central India. Proceedings of the Royal Society B: Biological Sciences, 280, 1506. https://doi.org/10.1098/rspb.2013.1506

Marshall, A. J., Lacy, R., Ancrenaz, M., Byers, O., Husson, S. J., Leighton, M.,...... \& Wich, S. A. (2009). Orangutan population biology, life history, and conservation. In: orangutans: geographic variation in behavioral ecology and conservation. New York: Oxford Univ. Press.

Megaze, A., Balakrishnan, M., \& Belay, G. (2017). Human-wildlife conflict and attitude of local people towards conservation of wildlife in Chebera Churchura National Park, Ethiopia. African Zoology, 52, 1-8. https://doi.org/ 10.1080/15627020.2016.1254063.

Meijaard, E., Rijksen, H. D., \& Kartikasari, S. N.. (2001). Diambang kepunahan : kondisi orangutan liar diawal abad ke-21. Jakarta: The Gibbon Foundation.

Meijaard, E., Sherman, J., Ancrenaz, M., Wich, S. A, Santika T., \& Voigt, M. (2018). Orangutan populations are certainly not increasing in the wild. Current Biology, 28(21), 1241-1242. https://doi.org/10.1016/j.cub.2018.09.052

Ministry of Environment and Forestry. (2019). Strategi dan rencana aksi konservasi Orangutan Indonesia 2019-2029. Jakarta: Direktorat Jenderal Konservasi Alam dan Ekosistem. Kementerian Lingkungan Hidup dan Kehutanan.

Ministry of Forestry, 2014. Peraturan No P.53/Menhut-II/2014 tentang Pedoman penanggulangan konflik manusia dan satwa liar. Jakarta: Departemen Kehutanan

Morrison, M. L., Marcot, B., \& Mannan, W. (2012). Wildlife-habitat relationships: concepts and applications, $3^{\text {rd }}$ Edition. Washington: Island Press.

Nasution, A., Farajallah, D.P., \& Atmoko, S.S.U. (2018). Nesting characteristics of the tapanuli orangutan (Pongo tapanuliensis) in two unprotected forests of Batang Toru, North Sumatra. Tropical Life Sciences Research, 29(2), 77-87. https://doi.org/ 10.21315/tIrs2018.29.16.

Nater, A., Mattle-Greminger, M. P., Nurcahyo, A., Nowak, M. G., de Manuel, M., Desai, T.,....., \& Kru"tzen, M. (2017). Morphometric, Behavioral, and Genomic Evidence for a New Orangutan Species. Current Biology, 27, 1-12. https://doi.org/ 10.1126/sciadv.1500789.

Neelakantan, A., DeFries, R., \& Krishnamurthy, R. (2019). Resettlement and landscape-level conservation: Corridors, human-wildlife conflict and forest use in Central India. Biological Conservation, 232, 142-151. https://doi.org/10.1016/j.biocon.2019.01.033

Nelson, E. J., Withey J. C, Pennington, D., \& Lawler, J. J. (2017). Identifying the impacts of critical habitat designation on land cover change. Resource and Energy Economics, 47, 89-125. https://doi.org/10.1016/j.reseneeco.2016.12.002 .

Oliveira, R. A. C., Marques, R., \& Marques, M. C. M. (2019). Plant diversity and local environmental conditions indirectly affect litter decomposition in a tropical forest. Applied Soil Ecology, 134, 45-53. https://doi.org/10.1016/j.apsoil.2018.09.016

Pandong, J., Gumal, M., Aton, Z. M., Sabki, M. S., \& Koh, L. P. (2019). Threats and lessons learned from past orangutan conservation strategies in Sarawak, Malaysia. Biological Conservation, 234, https://doi.org/10.1016/j.biocon.2019.03.016

Perbatakusuma, E. A, Supriatna, J., Siregar, R. S. E., Wurjanto, D., Sihombing, L., \& Sitaparasti, D. (2006). Mengarustamakan kebijakan konservasi biodiversitas dan sistem penyangga kehidupan di kawasan hutan alam Sungai Batangtoru Provinsi Sumatera Utara. Laporan Teknik Program Konservasi Orangutan Batangtoru. Jakarta: Conservation International IndonesiaDepartemen Kehutanan. 
Pliscoff, P., Simonetti, J. A., Grez, A. A., Vergara, P. M., \& Barahona-Segovia, R. M. (2020). Defining corridors for movement of multiple species in a forest-plantation landscape. Global Ecology and Conservation. https://doi.org/10.1016/j.gecco.2020.e01108

Rahman, D. E, Rinaldi, D., Kuswanda, W., Siregar, R., Noor, C. F., Hakim, F., Arief, H., \& Putro, H. R. (2019). Determining the landscape priority and their threats for the critically endangered Pongo tapanuliensis population in Indonesia. Biodiversitas, 20(12): 3584-3592. https://doi.org/0.13057/biodiv/d201217

Rakshya, T. (2016). Living with wildlife: Conflict or co-existence. Acta Ecologica Sinica, 36(6): 509514. https://doi.org/10.1016/j.chnaes.2016.08.004

Rockwood, L. L (2006). Introduction to population ecology. Australia: Blackwell Publishing.

Roth, T. S., Rianti, P., Fredriksson, G. M., Wich, S. A., \& Nowak, M. G. (2020). Grouping behavior of Sumatran orangutans (Pongo abelii) and Tapanuli orangutans (Pongo tapanuliensis) living in forest with low fruit abundance. American Journal of Primatology, e23123. https://doi.org/10.1002/ajp.23123.

Russon, A. E. (2010). Life History: The Energy-Efficient Orangutan. Current Biology, 20(22). https://doi.org/10.1016/j.cub.2010.10.003

Sandel, B. (2015). Towards a taxonomy of spatial scale-dependence. Ecography, 38, 358-369. https://doi.org/10.1111/ecog.01034

Scanes, C. G. (2018). Human activity and habitat loss: destruction, fragmentation, and degradation, In animals and human society. Cambridge: Academic Press. https://doi.org/10.1016/B978-012-805247-1.00026-5

Seddon, A. W. R. M., Macias, F., \& Long, P. R. (2016). Sensitivity of global terrestrial ecosystems to climate variability. Nature, 531 (7593). https://doi.org/10.1038/nature16986

Shannon, C. E. (1948). A mathematical theory of communication. Bell System Technical Journal, 27, 379-423.

Simorangkir, R. A. (2009). Study of Habitat and Estimation of Orangutan Population (Pongo abelii) in the Batangtoru Forest Area, North Sumatra. Thesis (unpublished). Bogor : Bogor Agricultural Institute.

Sinaga, T. (1992). Study of orangutan habitat and behavior (Pongo abelii) in Bohorok Gunung Leuser National Park. Thesis (unpublished). Bogor : Bogor Agricultural Institute.

Strubelt, I., Diekmann, M., Peppler-Lisbach, C., Gerken, A., \& Zacharias, D. (2019). Vegetation changes in the Hasbruch forest nature reserve (NW Germany) depend on management and habitat type. Forest Ecology and Management, 444, 78-88. https://doi.org/10.1016/j.foreco.2019.04.030

Sugardjito, J., te Boekhorst. I. J. A., \& van Hooff, J. A. R. A. M. (1987). Ecological constraints on the grouping of wild orangutans (Pongo pygmaeus) in the Gunung Leuser National Park, Sumatra, Indonesia. International Journal of Primatology, 8, 17-41. https://doi.org/10.1007/BF02737112

Tabares, X., Mapani, B., Blaum, N., \& Herzschuh, U. (2018). Composition and diversity of vegetation and pollen spectra along gradients of grazing intensity and precipitation in southern Africa. Review of Palaeobotany and Palynology, 253, 88-100. https://doi.org/10.1016/ j.revpalbo.2018.04.004

Templeton, L. K, Neel, M. C., Groffman, P. M., Cadenasso, M. L., \& Sullivan, J. H. (2019). Changes in vegetation structure and composition of urban and rural forest patches in Baltimore from 1998 to 2015. Forest Ecology and Management, 454. https://doi.org/10.1016/j.foreco.2019.117665

Tscharntke, T., Tylianakis, J. M., Rand, T. A., Didham, R.K., Fahrig, L., Batáry, P.,..... \& Westphal, C. (2012). Landscape moderation of biodiversity patterns and processes - eight hypotheses. Biological reviews of the Cambridge Philosophical Society, 87, 661-685. https://doi.org/10.1111/j.1469-185X.2011.00216.x 
Tsujino, R., Yumoto, T., Kitamura, S., Djamaluddin, I., \& Darnaedi, D. (2016). History of forest loss and degradation in Indonesia. Land Use Policy, 57, 335-347. https://doi.org/10.1016/j.landusepol.2016.05.034

Uddin, M.M., Ahsan, M.F., \& Lingfeng, H. (2020). Human-Primates Conflict In Bangladesh: A Review. The Journal of Animal \& Plant Science, 30(2), 280-287. https://doi.org/10.36899/JAPS.2020.2.0055

van Casteren, A., Sellers, W.I., Thorpe, S.K.S., Coward, S., Crompton, R.H., Myatt, J.P., \& Ennos, A.R. (2012). Nest-building orangutans demonstrate engineering know-how to produce safe, comfortable beds. Proceedings of the National Academy of Sciences, 109: 6873-6877.

Vesco, P., Dasgupta, S., De Cian, E., \& Carraro, C. (2020). Natural resources and conflict: A metaanalysis of the empirical literature. Ecological Economics, 172. https://doi:10.1016/j.ecolecon.2020.106633

Wich, S. A., Fredriksson, G. M., Usher, G., Peters, H. H., Priatna, D., Basalamah, F., ,....., \& Kühl, H. (2012). Hunting of Sumatran orang-utans and its importance in determining distribution and density. Biological Conservation, 146, 163-169. https://doi.org/10.1016/j.biocon.2011.12.006

Wich, S. A, Usher, G., Peters, H. H., Khakim, M. F. R, Nowak, M. G., \& Fredriksson, G.M. (2014). Preliminary data on the highland Sumatran orangutan (Pongo abelii) of Batang Toru. In NB Grow et al. (eds.). High altitude primates, development in primatology: progress and perspective. Springer Science+Business Media, 265-283.

Wich, S. A, Singleton, I., Nowak, M. G., Atmoko, S. S. U., Nisam, G., Arif, S. M., \& Kühl, H. S. (2016). Land cover changes predict steep declines for the Sumatran orangutan (Pongo abelii). Science Advance, 2(3), e1500789. https://doi.org/10.1126/sciadv.1500789

Willie, J., Petre, C. A. Tagg, N., \& Lens, L. (2012). Evaluation of species richness estimators based on quantitative performance measures and sensitivity to patchiness and sample grain size. Acta Oecologica, 45, 31-41. https://doi.org/10.1016/j.actao.2012.08.004.

Willis, K. J., Jeffers, E. S., \& Tovar, C. (2018). What makes a terrestrial ecosystem resilient? A complex set of biotic and abiotic factors determines the resilience of an ecosystem. Science, 359, 988989. https://doi.org/10.1126/science.aar5439 